\title{
Evaluation of the Effectiveness of a Training Program on Violence against Children and Adolescents
}

\section{Avaliação da Eficácia de um Programa de Formação sobre Violência contra Crianças e Adolescentes}

\author{
Murilo Sabbag Moretti $i^{I}(\mathbb{D}$ \\ Alex Sandro Gomes Pessoa ${ }^{I I}$ (D
}

\section{KEYWORDS}

- Violence.

- Children.

- Adolescents.

- Health Professionals.

- Program.

- Effectiveness.
${ }^{1}$ Universidade do Oeste Paulista, Presidente Prudente, São Paulo, Brazil.

${ }^{\mathrm{II}}$ Universidade Federal de São Carlos, São Carlos, São Paulo, Brazil.

Introduction: Assistance in health services is often the first possibility for the identification of cases of Violence Against Children and Teenagers (VACT). Therefore, the aim of this article was to evaluate the effectiveness of an intervention program developed to enable students and health professionals to recognize and report cases of VACT. Additionally, we sought to verify at what level of training (undergraduate, postgraduate or working professional) such intervention would show the greatest effect. Method: This is a quasi-experimental study, of which design was based on the analysis of a non-equivalent Control Group (CG). The research included undergraduate medical students, postgraduate medical students attending pediatric residency and professionals working in health institutions. A total of 105 people participated, of which $89 \%$ were women. The participants were subsequently subdivided between the Experimental Group - EG $(n=60)$ and Control Group - CG $(n=45)$. A training program on the topic, consisting of 10 sessions (20h in total), was developed and applied with an EG. To assess the effectiveness of the intervention, a questionnaire was applied at previously determined periods (pre-test and post-test). The data were submitted to statistical analysis (descriptive analyses, $t$ test and Tukey's multiple comparison test), using the software $R$. Results: The post-test showed statistically significant changes in all dimensions evaluated with the EG, which proves that the intervention resulted in changes regarding the previous conceptions that the participants had about VACT. Additionally, when comparing the responses obtained in the questionnaires between the three EG groups (undergraduate, postgraduate students and working professionals), it was verified that there were no statistical differences between the groups, suggesting that educational programs have positive effects on all levels of training. Conclusions: This study showed that training programs can qualify the conception of students and health professionals, as well as help them feel more prepared to deal with the demands related to VACT. However, a collective effort is needed so that these contents are purposefully incorporated into the training process at all levels, from undergraduate school to continuing education. 


\section{PALAVRAS-CHAVE}

- Violência.

- Criança.

- Adolescente.

- Profissionais de Saúde.

- Programa.

- Efetividade.

Received on $7 / 12 / 20$

Accepted on $8 / 14 / 20$

\section{RESUMO}

Introdução: O atendimento em serviços de saúde é, muitas vezes, a primeira possibilidade para a identificação de casos de violência contra crianças e adolescentes (VCCA). Sendo assim, o objetivo deste artigo foi avaliar a eficácia de um programa de intervenção desenvolvido para habilitar estudantes e profissionais da área da saúde a reconhecer e encaminhar casos de VCCA. Adicionalmente, buscou-se verificar em qual nível de formação (graduação, pós-graduação ou profissionais em exercício) uma intervenção desse porte teria maior efeito. Método: Trata-se de um estudo quase experimental, delineado a partir de uma análise com um grupo controle (GC) não equivalente. A pesquisa incluiu estudantes de Medicina, pós-graduandos da residência em pediatria e profissionais que atuam em instituições de saúde. Participaram, no total, 105 pessoas, sendo 89\% de mulheres. Os participantes foram posteriormente subdivididos entre o grupo experimental - GE $(n=60)$ e grupo controle - GC $(n=45)$. Um programa de formação, composto por dez sessões (20 horas no total), acerca do tema foi desenvolvido e aplicado a um GE. Para avaliar a efetividade da intervenção, aplicou-se um questionário em períodos previamente determinados (pré-teste e pós-teste). Os dados foram submetidos a análises estatísticas (análises descritivas, teste $t$ e de comparações múltiplas de Tukey), por meio do software R. Resultados: O pós-teste revelou alterações estatisticamente significativas em todas as dimensões avaliadas com o GE, o que comprova que a intervenção trouxe mudanças nas concepções prévias que os participantes tinham a respeito da VCCA. Além disso, quando se compararam as respostas obtidas nos questionários entre três grupos do GE (graduandos, pós-graduandos e profissionais em exercício), ficou constatado que não houve diferenças estatísticas intergrupos, o que sugere que programas desse porte têm efeitos positivos independentemente do nível da formação que está sendo ofertada. Conclusões: Este estudo evidenciou que programas de formação podem qualificar a concepção dos estudantes e profissionais da saúde, bem como auxiliar para que se sintam mais preparados para lidar com demandas relativas à VCCA. Cabe, no entanto, um esforço coletivo para que esses conteúdos sejam incorporados de forma propositiva no processo formativo em todos os níveis, da graduação à formação continuada.

\section{INTRODUCTION}

Violence is a major cause of morbidity and mortality in children and teenagers ${ }^{1}$. Given the consequences for the victims' physical and psychological health, this is a topic that must be widely debated in all public policy sectors. However, the initial and continuing training of health professionals is focused almost exclusively on the health-disease binomial, which results in the professionals' unpreparedness to face situations such as Violence Against Children and Teenagers (VACT) ${ }^{2,3}$.

The study by Koifman et al. ${ }^{4}$ carried out with medical students at Universidade Federal Fluminense, showed that the majority of participants (53\%) had never had access to the VACT topic during undergraduate school. The subject was considered to have been adequately addressed by only $9 \%$ of the students, who had no doubts about the subject, while $44 \%$ reported not feeling prepared to deal with this issue in their professional practice. Also in the same study, during interviews with resident physicians, half of them reported not having had training experiences related to the topic and only one participant stated that he felt confident in his capacity to identify cases, although he showed inaccurate knowledge about the correct conduct to be followed in the presence of a VACT case $\mathrm{s}^{4}$. These findings are similar to the results obtained in the study conducted by Margarido et al. ${ }^{5}$ and Nunes et al. ${ }^{6}$ with doctors working in the Family Health Program (currently called Family Health Strategy - FHS).

Similarly, another study carried out with medical, dentistry and nursing students from Universidade Federal de Santa Catarina ${ }^{7}$ showed that the concept of violence among the interviewees is related only to the physical damage caused to the victim. The feelings most frequently reported by the participants when treating VACT cases were fear and impotence, since, for the students, there is a distancing between the professional and the population's social problems. In the curriculum of these courses, the researchers conclude, little is discussed about protocols for assisting victims of violence ${ }^{7}$. The lack of technical information leads to these professionals' unpreparedness to recognize VACT, especially in cases with more subtle signs and symptoms ${ }^{4}$. In the study by Silveira et al. ${ }^{8}$, carried out with professionals from the Basic Health Units (BHU), it was found that physical signs and symptoms are prioritized, to the detriment of behavioral and emotional symptoms.

The raising of suspicion depends on the professionals' emotional aspects and the technical training they receive $e^{9,7}$. Moreover, there is an underreporting of VACT cases due to the fear of legal involvement that this conduct entails, as well as the absence of legal mechanisms to protect the professional and, even, due to the threats they suffered by the perpetrators of violence ${ }^{10,11}$. The absence of spaces for initial and continuing training, the excess of routine activities, the limited time to carry out consultations, the lack of privacy to establish a dialogue with patients and the reduced resources also contribute to the underdetection of VACT cases $^{12}$.

However, treatment at an emergency room, BHU, FHS, outpatient clinic or office is often the first possibility to recognize violence. Doctors, nurses and other health professionals should be aware of the risk factors, signs and symptoms identified in patients. Therefore, it is necessary to incorporate ways to alleviate the theoretical and practical learning deficit on the VACT topic into the undergraduate and postgraduate curricula ${ }^{12,13,4}$.

In Brazil, as well as in several countries around the world, there

REVISTA BRASILEIRA DE EDUCAÇÃO MÉDICA

2 44 (4) : e127; 2020 
are legal implications for health professionals who fail to notify public authorities about a suspected case of VACT. The Child and Adolescent Statute - ECA (Estatuto da Criança e do Adolescente) ${ }^{14}$ in its Article 245 states that "it as a crime for the physician, teacher or individual responsible for the health care and elementary education, pre-school or daycare, to fail to report to the competent authority about the cases they are aware of, which involve suspicion or confirmation of mistreatment against children or adolescents", under penalty of a fine of three to twenty reference salaries, twice as much in case of re-incidence. Therefore, health professionals need to deal with different types of feelings and situations for which they do not feel prepared, although they might answer legally for their actions ${ }^{6,9}$.

The reporting of VACT cases identified in health services is essential for the interruption of the violence cycle and to refer victims to the psychosocial care network. The notification of cases, either suspected or confirmed, is present in the Codes of Ethics of several health professionals and does not constitute breach of confidentiality. Ordinance n. 104 of the Ministry of Health establishes the compulsory notification of new cases of diseases and injuries, including violence, and Ordinance n. 1968, of October 2001, establishes that those responsible for the health units of the Unified Health System (SUS) must notify the Child Protective Services of any suspected or confirmed case of $\mathrm{VACT}^{10,11,9}$.

Given the possible consequences of violence in the lives of children and teenagers, it is understood as essential to include content about this phenomenon in the initial and continuing education of health professionals. The absence of training spaces has implications on the difficulty of recognizing and referring cases, perpetuating the condition of the violation of rights. Therefore, it is essential to develop pedagogical proposals and educational models on the topic that can contribute to the training of these professionals, enabling them to be better prepared when faced with VACT cases.

Based on these considerations, the aim of this article was to evaluate the effectiveness of an intervention program designed to allow students and health professionals to recognize and refer VACT cases. As a secondary objective, we aimed to verify at what level of training (undergraduate, postgraduate and working professional) such an intervention would have a greater effect.

\section{METHOD}

This research is a quasi-experimental study, of which design was based on an analysis that used pre- and post-test with a non-equivalent control group $^{16}$. Therefore, the field research was structured with a group that participated in the intervention program (Experimental Group - EG) and another that did not participate in any phase (Control Group - CG). Both groups were evaluated regarding their knowledge about the VACT topic, before and after the end of the intervention. Although the fieldwork produced qualitative and quantitative data to assess the program effectiveness, priority was given to data from the quantitative analysis in this article.

\section{Participants and Institutions}

The study included undergraduate medical students, postgraduate students attending medical residency in pediatrics and professionals working in health institutions. A total of 105 people participated, of which $89 \%$ were women. Participants were further subdivided into the
Experimental Group - EG ( $\mathrm{n}=60$; Age $-\mathrm{M}=27.2 ; \mathrm{SD}=9.7)$ and the Control Group - CG ( $\mathrm{n}=45$; Age - $\mathrm{M}=28.8$; $\mathrm{SD}=6.03$ ).

As one of the objectives of the study was to verify at which level of education a program of this size would have the greatest effect, the intervention was carried out separately with the participants of the EG, with the subgroups being constituted as follows: undergraduate students - 23 students from the ninth to the twelfth semesters of the School of Medicine of a private university in the countryside of São Paulo constituting the EG, and 21 undergraduate students attending the eighth semester of Medicine from the same university constituted the CG; Postgraduate students - 18 postgraduate students in pediatrics from a tertiary hospital in the countryside of São Paulo were allocated to the EG and 14 postgraduate students in pediatrics from a state university in the countryside of Paraná to the CG; Health Professionals - 19 medical professionals, nurses and psychologists working in the municipal health care network and on-call doctors at the pediatric emergency room of a regional hospital in a medium-sized municipality located in the countryside of the state of São Paulo integrated the EG of this subgroup, whereas 10 professionals from a tertiary hospital in the countryside of São Paulo comprised the CG. In other words, for each of the EG subgroups, a Control Group (CG) was created, with the same characteristics. As mentioned before, the participants of the CG were submitted to the pre and post-test but did not participate in the program.

\section{Instrument}

At the start of the research, an instrument that would be used to evaluate the conceptions of health professionals about the VACT theme was not found. Thus, to verify the effectiveness of the intervention, a questionnaire adapted from Ferrari et al. ${ }^{17}$ was used. After the alterations and, because this instrument has not been validated in the Brazilian context, the items were submitted to judges, that is, researchers with known experience in the field in which the research is included. As recommended by Hernández-Nieto ${ }^{18}$, the evaluators analyzed the material based on the clarity of language, pertinence and theoretical relevance (details can be found in Moretti et al. ${ }^{3}$ ).

In its final version, the instrument was structured into three sections: 1) sociodemographic data; 2) conceptions about violence against children and adolescents, including physical, sexual, psychological violence, neglect and abandonment; 3 ) perception of the health professional's performance in the presence of VACT cases. The items in the last two sections were structured as a Likert Scale model (with 5 points), with answers whose alternatives varied between totally disagree, disagree, neither agree nor disagree, agree and totally agree. Some of the items had inverted values, but the participants' answers indicated two central aspects for the study: i) the level of knowledge of professionals and students about VACT, including symptomatic manifestations, myths and taboos, typification of VACT, among others; ii) knowledge related to the social role of health professionals related to the referral of complaints in VACT cases, service flowchart, legal dimensions and perception of ethical responsibility.

\section{Description of the intervention}

The program was developed based on a non-systematic review of national and international literature on theoretical, ethical and procedural aspects of health professionals' work in the presence of VACT cases identified in institutional contexts. In addition to the expository contents,

REVISTA BRASILEIRA DE EDUCAÇ̃̃O MÉDICA

3 44(4) : e127; 2020 
such as the presentation of epidemiological data and clinical diagnoses, the sessions favored interactive and dialogical activities among the participants. Strategies were used to motivate participation and debate, including the sharing of experiences and challenges the professionals had already faced in previous situations. Image and sound resources (images, videos and music), slides with theoretical content, clinical case studies and protocols recommended by the Ministry of Health were used. Additionally, at the end of each session, participants received a list of movies on the topic addressed at that meeting.

The program consisted of 10 sessions, with each meeting lasting 2 hours (totaling 20 hours) and was carried out once a week with each group. The sessions were performed by a pediatrician, with theoretical and practical experience in the assessed topic. The summary of the performed intervention is described in Table 1.

\begin{tabular}{|c|c|c|}
\hline \multicolumn{3}{|c|}{ Summary of the intervention } \\
\hline Session & Topic & Objective \\
\hline 1 & $\begin{array}{l}\text { The social construction } \\
\text { of childhood and } \\
\text { adolescence }\end{array}$ & $\begin{array}{l}\text { To conceptualize childhood and } \\
\text { adolescence from a historical and social } \\
\text { perspective }\end{array}$ \\
\hline 2 & $\begin{array}{l}\text { The types of violence } \\
\text { and their different } \\
\text { forms of manifestation }\end{array}$ & $\begin{array}{l}\text { To recognize manifestations of violence } \\
\text { present in society and its social and } \\
\text { psychological impacts in different } \\
\text { groups and social segments }\end{array}$ \\
\hline 3 & $\begin{array}{l}\text { Violence against } \\
\text { children and } \\
\text { adolescents }\end{array}$ & $\begin{array}{l}\text { To conceptualize violence against } \\
\text { children and adolescents based on their } \\
\text { different forms of manifestation }\end{array}$ \\
\hline 4 & Physical violence & $\begin{array}{l}\text { To recognize injuries, signs and } \\
\text { symptoms suggestive of physical violence }\end{array}$ \\
\hline 5 & Psychological violence & $\begin{array}{l}\text { To recognize symptoms, especially } \\
\text { psychological, of children and adolescents } \\
\text { exposed to psychological violence }\end{array}$ \\
\hline 6 & $\begin{array}{l}\text { Neglect and } \\
\text { abandonment }\end{array}$ & $\begin{array}{l}\text { To define neglect and abandonment, as } \\
\text { well as differentiate situations resulting } \\
\text { from the family's socioeconomic } \\
\text { precariousness }\end{array}$ \\
\hline 7 & Sexual violence: abuse & $\begin{array}{l}\text { To classify and recognize sexual } \\
\text { violence against children and } \\
\text { adolescents, considering situations of } \\
\text { sexual abuse }\end{array}$ \\
\hline 8 & $\begin{array}{l}\text { Sexual violence: } \\
\text { exploitation }\end{array}$ & $\begin{array}{l}\text { To classify and recognize sexual } \\
\text { violence against children and } \\
\text { adolescents, considering situations of } \\
\text { sexual exploitation }\end{array}$ \\
\hline 9 & $\begin{array}{l}\text { Complaints and } \\
\text { referrals }\end{array}$ & $\begin{array}{l}\text { To be aware of public policies, } \\
\text { institutions and protective equipment } \\
\text { for these segments and the flow chart } \\
\text { used to refer complaints }\end{array}$ \\
\hline 10 & $\begin{array}{l}\text { Self-protective } \\
\text { conducts }\end{array}$ & $\begin{array}{l}\text { To understand self-protective behavior } \\
\text { strategies against violence and learn } \\
\text { about ways to teach them to children } \\
\text { and adolescents }\end{array}$ \\
\hline
\end{tabular}

Source: Created by the Authors.

\section{Data Analysis and Procedures}

The research procedures were carried out in some stages, carefully planned by the researchers. Initially, the intervention was developed, as well as the creation of the instrument that would evaluate the pre and post-test indicators in the EG and CG. Before the program was started, the EG and the CG answered the questionnaire simultaneously. The program sessions took place in the hospital amphitheater or in lecture halls provided by the municipal health secretariat. After the end of the program, both the CG and the EG answered the instrument again.

The data obtained were submitted to descriptive statistical analysis, comparing the pre- and post-test questionnaires of the participating groups. To verify whether the measurements obtained before and after the program implementation were significantly different, the $t$-test was used. This procedure is used when one intends to verify whether a sample average is equal to or different from a reference value. When a difference between the means of the categories was identified, Tukey's multiple comparison tests were used as a complement to identify these differences between pairs of specific means or in linear combinations of the means ${ }^{19}$. Statistical analyses were performed using the $\mathrm{R}$ program, with the probability less than or equal to 0.05 (p-value $<0.05$ ) being considered as statistically significant.

\section{Ethical issues}

The project was submitted to the approval of the Research Ethics Committee (REC) for studies with Human Beings of Universidade do Oeste Paulista (UNOESTE), which evaluated the questions pertinent to the ethical precepts and all the necessary documentation before the start of any data collection procedure (Certificate of Ethical Appreciation: 80281317.2.0000.5515). The participants signed the Free and Informed Consent Form (FICF), in agreement with the methodological procedures. The sessions were held in a room that guaranteed the conditions of confidentiality and environmental adequacy. After data collection, the CG received a training course on the role of health professionals regarding the referral of cases of suspected VACT.

\section{RESULTS}

After applying the questionnaires to the EG and CG in the pre and post-test stages, the instrument items were analyzed to assess the effectiveness of the intervention. Table 2 shows the results by categories in which the questionnaire items were grouped: acceptance and naturalization of VACT, physical violence, sexual violence, psychological violence, neglect and professional performance.

No statistical difference was observed between the pre- and post-test in any of the categories in the CG. As for the EG, , there were statistically significant alterations in all the assessed dimensions, which proves that the intervention brought changes to the previous conceptions the participants had about the VACT topic. The significant difference that occurred in the professional performance category is highlighted, showing that after the training was provided, the participants felt more capable and confident regarding their performance in the presence of VACT cases, as well as safer for referral to the child and adolescent protection network.

When comparing the answers obtained in the questionnaires between the three groups (undergraduate students, postgraduate students and health professionals) aiming to verify in which group an intervention such as this would be more effective, it was found that there was no statistical 
difference between the groups (Table 3), although it is important to highlight that there were statistically significant improvements in the participants' VACT perceptions in all groups, as shown in Table 2. These data show that educational models or training programs on the VACT topic can be proposed at any stage of the health professionals training (at the undergraduate level, at the postgraduate level and as continuing education actions).

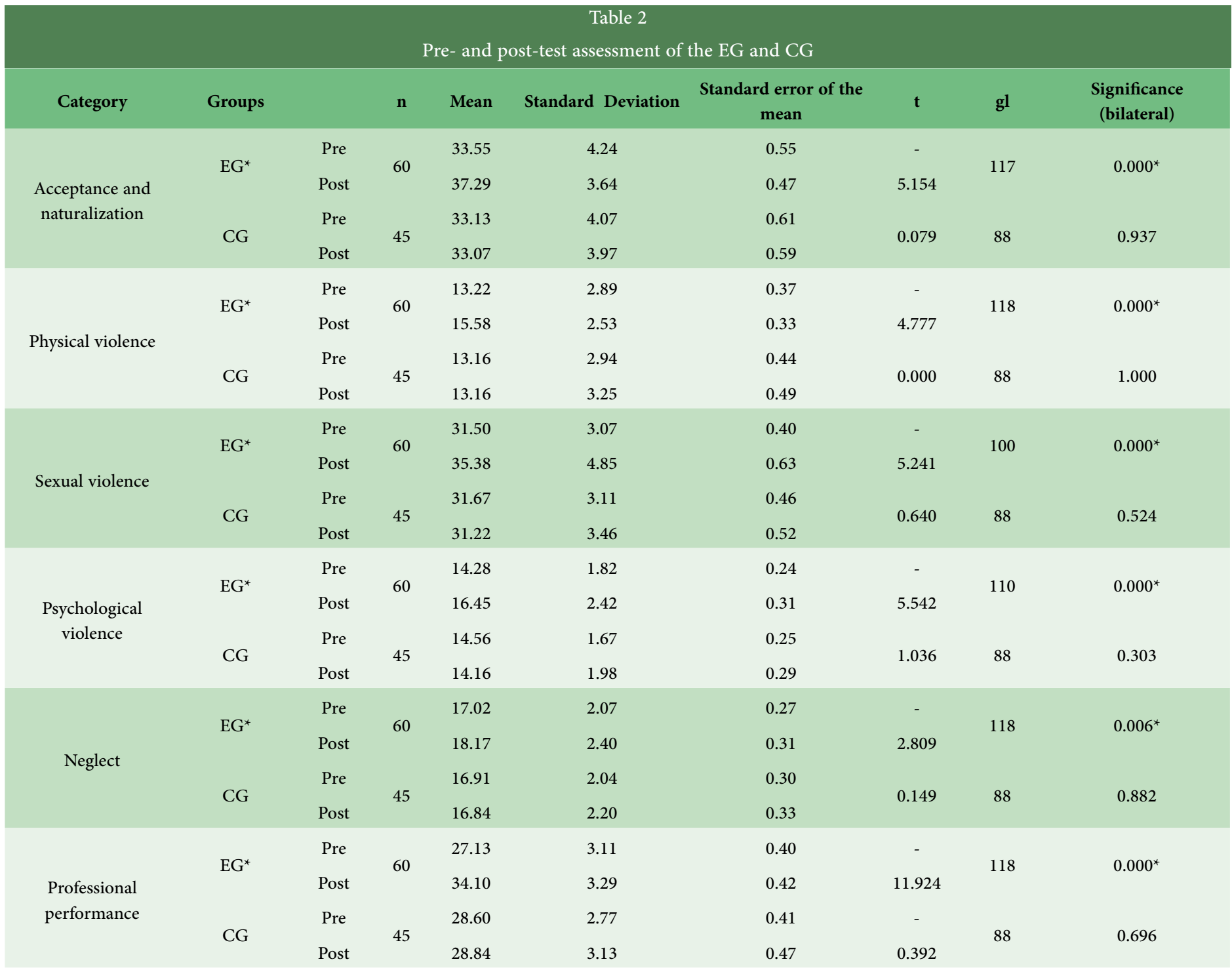

Note: ${ }^{*} \mathrm{p}<0.05$ ( $95 \%$ confidence interval).

Source: Created by the Authors.

Table 3

Comparison of the intervention effectiveness in the three participating groups

\begin{tabular}{|c|c|c|c|c|c|c|c|c|c|}
\hline Group & & $\mathbf{N}$ & Mean & $\begin{array}{l}\text { Standard } \\
\text { deviation }\end{array}$ & Standard error & $\begin{array}{l}\text { Lower limit } \\
\text { range }\end{array}$ & $\begin{array}{l}\text { Upper limit } \\
\text { range }\end{array}$ & Minimum & Maximum \\
\hline \multirow{2}{*}{$\begin{array}{l}\text { Undergraduate } \\
\text { students }\end{array}$} & Pre & \multirow{2}{*}{44} & 3.46 & 0.20 & 0.03 & 3.40 & 3.52 & 3.12 & 3.89 \\
\hline & Post & & 3.75 & 0.42 & 0.06 & 3.62 & 3.88 & 2.97 & 4.57 \\
\hline \multirow{2}{*}{ Postgraduate students } & Pre & \multirow{2}{*}{32} & 3.54 & 0.27 & 0.05 & 3.44 & 3.63 & 3.02 & 4.07 \\
\hline & Post & & 3.80 & 0.39 & 0.07 & 3.66 & 3.94 & 3.16 & 4.79 \\
\hline \multirow{2}{*}{ Working professionals } & Pre & \multirow{2}{*}{29} & 3.51 & 0.27 & 0.05 & 3.40 & 3.61 & 2.93 & 3.98 \\
\hline & Post & & 3.78 & 0.36 & 0.07 & 3.65 & 3.92 & 3.10 & 4.40 \\
\hline
\end{tabular}

Note: ${ }^{\star} \mathrm{p}<0.05$ (95\% confidence interval)

Source: Created by the Authors 


\section{DISCUSSION}

The Ministry of Health defines violence against children and teenagers as "any act or omission by parents, relatives, guardians, institutions and, ultimately, society in general, which result in physical, emotional, sexual and moral damage to the victims" ${ }^{20}$. It is necessary for professionals to accept that this is also a problem in the healthcare area and understand that they have a fundamental role regarding the coping with VACT. Mainly pediatric doctors and nurses, who are often responsible for the first assistance to victims, should be alert to cases that raise any suspicion ${ }^{13,4}$.

In addition to all clinical procedures, it is the duty of the pediatrician, together with the health team, to assess the severity, the risk of re-victimization and refer the complaint to the Child Protection Services and notification to SINAN (Information System for Notifiable Diseases). These conducts must be taken in any cases of suspicion or confirmation of violence, in addition to hospitalization in the presence of a severe case or risk for the child ${ }^{21,22}$. However, health professionals still have many difficulties regarding the VACT topic. For that reason, improving the courses offered in the educational institutions responsible for undergraduate and postgraduate students and continuing education in health is understood as essential. The gaps in the training process lead to a lack of information for the recognition and referral of cases $^{23}$.

This study showed that a well-structured training program produces important changes in the conception of health professionals and students about VACT, whereas it also collaborates to make them feel better prepared to deal with these demands. Despite the findings of this investigation, Christian $^{24}$ states that, in the international context, there are no surveys on the quantity and quality of programs designed specifically to prepare medical students for the VACT topic. Similarly, Gebara and Lourenço ${ }^{25}$ state that health professionals in the Brazilian context do not have training spaces to allow them to deal with this type of demand, and in many cases, knowledge on the subject occurs on their own initiative.

Studies carried out in the 1990s, such as the one by Dubowitz and Black $^{26}$, already indicated that by offering a series of 6 seminars, with each session lasting 90 minutes, was already capable of significantly increasing the knowledge of medical residency students about the violation of the rights of children and adolescents. The findings of the present study reinforce this statement, as a 20 -hour program showed to be effective and a successful endeavor. Moreover, the positive results were also extended to undergraduate students and professionals working in different public health policies.

Lise and Motta ${ }^{27}$ claim that VACT affects all socioeconomic, ethnic and religious strata. However, its effects are even more critical in groups exposed to situations of social vulnerability, especially those from families facing unemployment, caregivers' low level of schooling and scarcity of resources. On this subject, Christian ${ }^{24}$ warns that health students and professionals, especially in the medical field, might not understand the complexity of VACT precisely because they come from groups that are more socioeconomically favored. It is necessary that intervention programs for this group contextualize, in a non-stigmatized way, the sociocultural reality of families that, at times, also become victims of a perverse, excluding social organization model that promotes violence.

An urgent task for educational institutions that offer initial and continuing training courses for health professionals is the inclusion of disciplines and permanent training spaces that address these topics ${ }^{28}$. However, for Margarido et $\mathrm{al}^{5}$, the training curricula for medical professionals insist on decontextualized and uncritical teaching programs of social reality. Also according to the aforementioned authors, the curricula of these courses mainly respond to market demands and elitist practices, which ends up generating "a gap between the number of students graduating from training centers and the demands of public health services" ( p. 408).

This article does not aim to defend that it is the health professionals' exclusive responsibility to act in the identification of existing cases of VACT. But, unquestionably, these professionals can be decisive in recognizing this reality and greatly strengthening the victims' protection network. This study shows that training programs can qualify the professionals' conceptions, as well as help them feel more prepared to deal with these demands. However, it is necessary a collective effort to ensure that these contents are purposefully incorporated in the training process at all levels, from undergraduate school to continuing education.

\section{FINAL CONSIDERATIONS}

The objective of the study was to evaluate the effectiveness of an intervention model, aimed at students and professionals in the health area, capable of helping them in the identification and referral of cases of violence against children and teenagers. Moreover, we aimed to verify at what level of training such program would be the most effective. It was demonstrated, through statistical analysis, that the program was effective and achieved the proposed objectives, that is, it positively changed the previous concepts of students and professionals and prepared them for managing and dealing with VACT cases. It was also found that programs of this size produce positive results in students and professionals with different types of training and experience, which suggests that educational actions about VACT should be included in initial and continuing training programs in the health area courses.

This study has some limitations, such as, for instance, the impossibility of implementing the assessment of the follow-up level or even following the professionals and students longitudinally to verify the practical application of the knowledge acquired in the program. Therefore, it is recommended that future studies monitor and evaluate the performance of students and professionals in real-life situations. It is also noteworthy the fact that there are questions about the gains obtained from participating in a short-term program only, such as in this study. The specialized literature contains a wide debate on the need for such actions as this to be included intermittently in the training of health professionals. Therefore, this investigation raises new investigative questions and makes researchers in the area address the dilemmas that still persist on the topic.

\section{ACKNOWLEDGMENTS}

We thank Jhully Cristine Ananias Boaro and Amanda Barbosa Ferrador for their technical support provided in the manuscript finalization and the Coordination for the Improvement of Higher Education Personnel (CAPES -Coordenação de Aperfeiçoamento de Pessoal de Nível Superior Brasil) for the financial support - Financing Code 001. 


\section{REFERENCES}

1. Machado JC, Rodrigues VP, Viela ABA, Simões AV, Morais RLGL, Rocha EM. Violência intrafamiliar e as estratégias de atuação da equipe de saúde da família. Saúde Soc. 2014;23(3): 828-40.

2. Malta DC, Mascarenhas MDM, Bernal RTI, Viegas APB, Sá NNB, Silva Junior JB. Acidentes e violência na infância: evidências do inquérito sobre atendimentos de emergência por causas externas. Cienc Saude Colet. 2012;17(9):2247-58.

3. Moretti MS, Medeiros, JK, Pessoa, ASG, Koller, SH. Identificação e encaminhamentos de casos de violência contra crianças no contexto das políticas de saúde. In: Vestena CLB, D’Aroz, MS, Costa-Lobo C, org. As Crianças: Infância, Pobreza e Qualidade de Vida. Curitiba: CRV;2019. p.167-186.

4. Koifman L, Menezes RM, Bohrer KR. Abordagem do tema "violência contra a criança” no curso de Medicina da Universidade Federal Fluminense. Rev Bras Educ Med. 2012;36(2):172-9.

5. Margarido A, Próspero ENS, Grillo LP. Violência doméstica contra crianças e adolescentes: formação e conhecimento dos médicos. Psicol Argum. 2013;31(74):405-14.

6. Nunes CB, Sarti AA, Ohara CVS. Concepções de profissionais de saúde sobre a violência intrafamiliar contra a criança e o adolescente. Rev Lat Am Enfermagem. 2008;16(1):136-41.

7. Rosa R, Boing AF, Schraiber LB, Coelho EBS. Violência: conceito e vivência entre acadêmicos da área da saúde. Interface Comun Saúde Educ. 2010;14(32):81-90 [acesso em 2 out. 2017]. Disponível em: https://www. scielo.br/scielo.php?script=sci_arttext\&pid=S1414-32832010000100007

8. Silveira TB, Oliveira AMN, Algeri S, Susin LRO, Baisch ALM, Marques LA, et al. The invisibility of psychological violence against children. J Hum Growth Dev. 2016;26(3):345-51.

9. Calza TZ, Dell'Aglio DD, Sarriera JC. Direitos da criança e do adolescente e maus-tratos: epidemiologia e notificação. Rev SPAGESP. 2016;17(1):14-27.

10. Cocco M, Silva EB, Jahn AC. Abordagem dos profissionais de saúde em instituições hospitalares a crianças e adolescentes vítimas de violência. Rev Eletrônica Enferm. 2010;12(3):491-7.

11. Garbin CAS, Dias IA, Rovida TAS, Garbin AJI. Desafios do profissional de saúde na notificação da violência: obrigatoriedade, efetivação e encaminhamento. Cienc Saude Colet. 2015;20(6):1879-90.

12. Moura ATMS, Moraes CL, Reichenheim ME. Detecção de maustratos contra a criança: oportunidades perdidas em servições de emergência na cidade do Rio de Janeiro, Brasil. Cad Saude Publica 2008;24(12):2926-36.

13. Paiva $C$, Zaher VL. Violência contra crianças: $\mathrm{o}$ atendimento médico $\mathrm{e}$ o atendimento pericial. Saúde, Ética \& Justiça. 2012;17(1):12-20.

14. Brasil. Lei no 8.069 , de 13 de julho de 1990. Dispõe sobre o Estatuto da Criança e do Adolescente e dá outras providências. Diário Oficial [da] República Federativa do Brasil, Brasília, DF; 16 jul. 1990.

15. Nunes CB, Sarti CA, Ohara CVS. Profissionais de saúde e violência intrafamiliar contra a criança e adolescente. Acta Paul Enferm. 2009;22(ed esp):903-8.
16. Cozby PC. Métodos de pesquisa em ciências do comportamento. São Paulo: Atlas; 2009.

17. Ferrari IMSF, Priolo Filho SR, Brino RF. Questionário sobre violência intrafamiliar: confiabilidade de um instrumento sobre crenças. Psicol Teor Prát. 2016;18(3):54-65.

18. Hernández-Nieto RA. Contributions to statistical analysis. Mérida: Universidade de Los Andes; 2002.

19. Vieira S. Bioestatística: tópicos avançados. Rio de Janeiro: Campus; 2003.

20. Brasil. Linha de cuidado para a atenção integral de crianças, adolescentes e suas famílias em situação de violências. Brasília: Ministério da Saúde; 2010.

21. Pfeiffer L, Rosário NA, Cat MNL. Violência contra crianças e adolescentes: proposta de classificação dos níveis de gravidade. Rev Paul Pediatr. 2011;29(4):477-82.

22. Sociedade Brasileira de Pediatria. Protocolo de abordagem da criança ou adolescente vítima de violência doméstica. Rio de Janeiro: SBP; 2018.

23. Bannwart TH, Brino RF. Dificuldades enfrentadas para identificar e notificar casos de maus-tratos contra crianças e/ou adolescentes sob a óptica de médicos pediatras. Rev Paul Pediatr. 2011;29(2):138-45.

24. Christian CW. Professional education in child abuse and neglect. Pediatrics. 2008;122(1):S13-7.

25. Gebara CFP, Lourenço LM. Crenças de profissionais da saúde sobre violência doméstica contra crianças e adolescentes. Psicol Pesq. 2008;2(1):27-39.

26. Dubowitz H, Black M. Teaching pediatric about child maltreatment. J Dev Behav Pediatr. 1991;12(5):305-7.

27. Lise F, Motta MGC. Violência doméstica infantil: abordagem da enfermagem. Acta Sci. 2012;34(1):53-8.

28. Rocha PCX, Moraes CL. Violência familiar contra a criança e perspectivas de intervenção do Programa de Saúde da Família: a experiência do PMF/Niterói (RJ, Brasil). Cien Saude Colet. 2011;16(7):3286-96.

\section{AUTHORS' CONTRIBUTION}

All authors were jointly responsible for the research project creation, intervention model, the questionnaire used in the study, the data analysis and the writing of the manuscript. The first author was responsible for carrying out the program sessions and collecting the data.

\section{CONFLICTS OF INTEREST}

The authors declare no conflicts of interest.

\section{ADDRESS FOR CORRESPONDENCE}

Murilo Sabbag Moretti. Faculdade de Medicina da Universidade do Oeste Paulista, Rua José Bongiovani, 700, Cidade Universitária, Presidente Prudente, SP, Brasil. CEP: 19050-920.

E-mail: murilomoretti@gmail.com 